\title{
Bordering on Legality: Canadian Church Sanctuary and the Rule of Law
}

\author{
Sean RehaAg
}

\begin{abstract}
This paper examines church sanctuary incidents in Canada involving unsuccessful refugee claimants seeking to avoid deportation. The author contends that when faith-based communities develop formal screening mechanisms to determine who among the many that request it is accorded sanctuary, they apply similar norms and procedures as those found in Canada's official refugee determination process. The author argues that although sanctuary practices are often criticized as a form of civil disobedience that poses a threat to the rule of law, it is also possible to understand sanctuary practices as a means through which faithbased communities prevent the state from violating both Canadian and international refugee law, thereby upholding rule-of-law norms.
\end{abstract}

\section{Résumé}

Cet article examine les cas de sanctuaire survenus au Canada dans une église impliquant des demandeurs d'asile déboutés visant à éviter la déportation. Lorsque les communautés confessionnelles, soutient l'auteur, mettent au point des mécanismes de contrôle formels pour déterminer à qui, parmi les nombreux demandeurs, accorder le sanctuaire, elles appliquent des normes et des procédures similaires à celles qu'on trouve dans le processus officiel canadien de détermination de réfugiés. Bien que ces pratiques de sanctuaire soient souvent critiquées comme une forme de désobéissance civile qui constitue une menace pour la primauté du droit, l'auteur soutient qu'il est également possible de les comprendre comme moyen par lequel les communautés confessionnelles empêchent l'État de porter atteinte au droit tant canadien qu'international des réfugiés, confirmant ainsi les normes de la règle de droit.

\section{Introduction}

Sanctuary is an institution which, in the Christian tradition, ${ }^{1}$ traces its roots to religious norms, ancient Greek and Roman law, medieval European law, and Catholic canon law. $^{2}$ In many Western states this institution was explicitly abolished as a matter of state law $\mathrm{w}^{3}$ by the early seventeenth century. ${ }^{4}$ However, sanctuary appears to be undergoing something of a revival in recent years. ${ }^{5}$

In Canada, most contemporary sanctuary incidents involve unsuccessful refugee claimants who allege that their claims were wrongly denied. With the permission of faithbased communities, these unsuccessful refugee claimants take up residence in sacred buildings, usually Christian churches. ${ }^{6}$ Canadian immigration officials are reluctant to enter churches for the purposes of enforcing immigration law. As a result, those taking sanctuary benefit from a de facto suspension of deportation while they remain within churches. In many cases, this suspension of deportation ultimately ends with migrants securing Canadian permanent residence through discretionary immigration procedures. $^{7}$

In media accounts and popular discourse about Canadian sanctuary incidents, arguments about the legality of these practices play a central role. To date, however, few legal scholars have critically assessed the competing legal claims at stake. This article seeks to offer such an assessment, focusing on evaluating rule-of-law arguments deployed by the proponents and critics of sanctuary.

The article begins by outlining Canadian sanctuary practices. Next it examines the screening mechanisms that Canadian churches deploy to decide who, among the many that request it, is accorded sanctuary. Interestingly, these screening mechanisms mimic the official refugee determination system: lawyers get involved, alleged fears of persecution are scrutinized, supporting country condition documentation is considered, and various interpretations of

(C) Sean Rehaag, 2009. This open-access work is licensed under a Creative Commons Attribution-NonCommercial 4.0 International License, which permits use, reproduction and distribution in any medium for non-commercial purposes, provided the original author(s) are credited and the original publication in Refuge: Canada's Journal on Refugees is cited. 
refugee law are propounded. The paper explores this curious phenomenon whereby sanctuary providers replicate the refugee determination process whose outcomes they reject. Then, through a close analysis of the relevant provisions of Canadian state law, the paper argues that, although sanctuary practices are frequently criticized on rule-of-law grounds as involving illegal acts of civil disobedience, it is not at all obvious that they should be considered as such. To the contrary, while there may be some rule-of law-arguments against Canadian sanctuary practices, it is also plausible to understand these practices as a means through which faithbased communities prevent the state from violating both Canadian and international refugee law.

\section{Canadian Church Sanctuary Practices}

\section{The Lippert Study: Canadian Sanctuary Incidents}

In Sanctuary, Sovereignty, and Sacrifice, Randy Lippert offers a comprehensive study of Canadian sanctuary practices. ${ }^{8}$ Drawing on the work of Paul Weller, who studied sanctuary incidents in Britain, ${ }^{9}$ Lippert suggests that sanctuary can involve either exposure or concealment strategies. When sanctuary providers employ exposure strategies they make sustained efforts to publicize the stories of those accorded sanctuary in the hopes that such publicity will make it politically difficult for state officials to undertake deportation activities. In contrast, when sanctuary providers resort to concealment strategies they actively hide those taking sanctuary so as to avoid their detection by state officials and the deportation that might follow from that detection. ${ }^{10}$ In his study of Canadian sanctuary incidents, due in part to methodological considerations, Lippert concentrates on the former. For the purposes of his study, he defines sanctuary as "those incidents in which migrants actually entered and remained in ... [a church] to avoid deportation and that entailed strategic efforts to expose this fact to mass media, communities, and political authorities." 11

Based on this definition, Lippert identifies thirty-six sanctuary incidents in Canada during a twenty-year period beginning in 1983, when the first known instance of Canadian church sanctuary occurred. ${ }^{12}$ These thirty-six incidents concerned 261 migrants of twenty-eight different nationalities. ${ }^{13}$ All but two incidents involved non-citizens subject to deportation who had previously made unsuccessful refugee claims in Canada and who continued to allege that they faced serious risks of persecution abroad. ${ }^{14}$

Perhaps the most striking of Lippert's findings relates to the outcomes of sanctuary incidents. In all thirty-six cases, sanctuary successfully delayed deportation. ${ }^{15}$ Moreover, during the twenty-year period of the study, the police and immigration officials refrained from entering churches to arrest migrants in sanctuary. ${ }^{16}$ Similarly, no sanctuary providers were charged with violating Canadian law. ${ }^{17}$ More surprisingly, in 58 per cent of the sanctuary incidents Lippert identifies, migrants in sanctuary ultimately secured the legal right to remain in Canada indefinitely, usually as Permanent Residents. ${ }^{18}$ In the remaining cases, migrants either voluntarily left the church to go underground or to co-operate with their deportation (25 per cent), or the outcome was unclear or pending at the time of the study (14 per cent). ${ }^{19}$

Without wishing to downplay the hardship associated with spending several months physically confined to a church building that is not designed for human habitation, ${ }^{20}$ it must be said that the success rate that Lippert identifies in sanctuary incidents is truly remarkable. To put this rate in context, consider that the success rate in judicial reviews of negative refugee determinations is less than 2 per cent. ${ }^{21}$ Other means of delaying deportation are similarly ineffectual. ${ }^{22}$ In other words, sanctuary is one of the most effective avenues currently available to unsuccessful refugee claimants seeking the right to remain in Canada.

\section{Screening Procedures: Mimicking the Official Refugee Determination System}

One of the likely reasons sanctuary is so successful in Canada is that churches carefully screen applicants to ensure that only those who have strong cases for refugee protection are accorded sanctuary. ${ }^{23}$ As a result, far more migrants request sanctuary than are accorded it. Indeed, United Church pastor Darryl Gray, whose congregation offered sanctuary on two occasions, notes that he turns away requests for sanctuary on a weekly basis, "because they are often economic refugees who can't prove they face physical danger." 24

To help congregations screen applicants for sanctuary, the United Church has prepared a detailed pamphlet entitled Sanctuary for Refugees?: A Guide for Congregations. ${ }^{25}$ This 30-page pamphlet, in addition to reproducing the text of the refugee definition as established by the 1951 UN Convention relating to the Status of Refugees, ${ }^{26}$ recommends steps that can be taken to determine whether those requesting sanctuary meet the refugee definition. Included among those recommendations is the following:

A congregation ... considering a request for sanctuary ... must learn as much as possible about that person to determine whether or not this is a bona fide claim. Over two to three interviews ... it is essential to learn as much as possible about the person's story. In the interest of clarity, no reasonable question should be ignored or considered impolite or irrelevant.

(C) Sean Rehaag, 2009. This open-access work is licensed under a Creative Commons Attribution-NonCommercial 4.0 International License, which permits use, reproduction and distribution in any medium for non-commercial purposes, provided the original author(s) are credited and the original publication in Refuge: Canada's Journal on Refugees is cited. 
Check the merits of the case with representatives of the United Nations High Commissioner for Refugees and Amnesty International ... Find out whether the country has a history of gross and systemic human rights violations and tolerates the persecution of minority groups ... Country Reports are also available through regional Documentation Centres of the Immigration and Refugee Board. ${ }^{27}$

What is interesting about these and other passages in the guide is that they tell United Church congregations to carefully screen applicants for sanctuary using essentially the same legal tests, the same means of evaluating testimony, and even the same documentary evidence regarding country conditions that are employed in the official Canadian refugee determination process. Moreover, the United Church is not the only denomination to develop formal screening practices that mimic the official refugee determination system in this manner. The Presbyterian Church, for example, has issued guidelines that offer essentially the same advice. ${ }^{28}$

Given the existence of such guidelines, it is likely that the small number of migrants who successfully pass through sanctuary screening procedures have highly persuasive cases. It is therefore understandable that, in combination with pressure brought to bear on political actors, sanctuary providers are frequently able to persuade immigration officials to exercise their discretion to grant exceptions on humanitarian and compassionate grounds to the regular rules regarding qualification for Canadian Permanent Residence. ${ }^{29}$

\section{Policy Change and Sanctuary Incidents}

In addition to the success of Canadian sanctuary incidents at the level of individual cases, there is also some indication that sanctuary practices in Canada may be effective at the level of policy change. According to Lippert's study, the frequency of Canadian sanctuary incidents is increasing. Indeed, 19 per cent of the sanctuary incidents Lippert identified from 1983 through 2003 occurred in $2003 .^{30}$ One of the reasons for this increase is a frustration that sanctuary providers display towards a feature of Canada's refugee determination system. ${ }^{31}$ Canada's current immigration legislation, passed in 2001, sets out a procedure through which unsuccessful refugee claimants may have their initial refugee determinations reviewed on their merits by the Refugee Appeal Division (RAD) of the Immigration and Refugee Board. ${ }^{32}$ The Canadian government, however, selectively implemented the provisions of the legislation, bringing the provisions of the legislation into force ${ }^{33}$ except those pertaining to the RAD. ${ }^{34}$ According to the United Church's pamphlet on sanctuary, until the appeal comes into force 'refugee determinations' will continue to be made without the benefit of a sober second opinion or an effective way to correct factual errors. This ... has increased the chances of bona fide refugees being deported. ${ }^{35}$

Similarly, according to a declaration by the Interfaith Sanctuary Coalition:

Any system of adjudication is open to error. That is why virtually every decision-making process involving rights of any significance gives rise to a right of appeal. Since the abolition of capital punishment in Canada, the decision to grant or refuse refugee determination status is the only judicial decision in Canada which can result in someone's death.

Despite the extreme gravity of the refugee determination decision, there is no appeal on the merits available to refused refugee claimants ... The lack of appeal [is] ... the most important flaw in Canada's refugee determination system, since its inception in $1989 .{ }^{36}$

In 2006, in response to these and similar critiques, ${ }^{37}$ Bloc Québécois MP Nicole Demers introduced a Private Member's Bill requiring the government to immediately proclaim the coming into force of the legislative provisions establishing the RAD. ${ }^{38}$ At the time of writing, the Bill had passed the third reading in the House of Commons, and appeared likely to be passed in the Senate. However, the Bill was placed on hold by the decision of the Harper government to call an election in the fall of 2008. Nonetheless, it is worth noting that in Parliamentary debates regarding the RAD - including debates surrounding this Bill - the failure to implement the RAD is frequently and explicitly linked to the fact that unsuccessful refugee claimants who say that mistakes were made in their initial refugee determination resort to church sanctuary to avoid deportation. ${ }^{39}$ It thus seems that sanctuary practices have been influential not just in assisting individual migrants, but also in contributing to the larger debates about Canadian refugee policy.

\section{Recent Trends: Violations of Sanctuary}

It must be acknowledged that two recent cases, at first glance, appear to suggest that sanctuary may be less successful today than it was during the period of Lippert's study (i.e. 1983-2003).

The first incident occurred on March 5, 2004, when police officers stormed the Saint-Pierre United Church in Quebec City. The police officers were searching for Mohamed Cherfi, an Algerian political activist who had made an unsuccessful refugee claim and who was subject to a deportation order. ${ }^{40}$ To avoid his imminent deportation, Cherfi had publicly taken

(C) Sean Rehaag, 2009. This open-access work is licensed under a Creative Commons Attribution-NonCommercial 4.0 International License, which permits use, reproduction and distribution in any medium for non-commercial purposes, provided the original author(s) are credited and the original publication in Refuge: Canada's Journal on Refugees is cited. 
sanctuary in the church after convincing the church community that he faced a serious risk of persecution should he be removed to Algeria. In the first known violation of sanctuary in Canada, Cherfi was arrested inside the church and taken to a police station, where he was immediately transferred to the custody of Canadian Border Service Agency (CBSA) officials. Several years prior, Cherfi had transited to Canada via the United States. Thus, to effect his deportation, CBSA officials drove him directly to the border, where he was turned over to US immigration authorities. ${ }^{41}$

The second incident occurred on February 17, 2007, when a police officer arrested Amir Kazemian inside an Anglican church in Vancouver. Kazemian, also an unsuccessful refugee claimant subject to a deportation order, had been in sanctuary in the church for almost three years. He alleged that his refugee claim had been wrongly denied, noting that his mother obtained refugee status in Canada (in a decision made by a different refugee adjudicator) on the basis of identical factual allegations. Curiously, there is no indication that the police set out to breach sanctuary in this case. In fact, it was Kazemian who called the police to the church to investigate a complaint about a client of an online business he ran from inside the church because the client had allegedly engaged in threatening behaviour. When the police officer arrived at the church and discovered the outstanding deportation order, however, she promptly arrested Kazemian. This move surprised Kazemian's supporters because other police officers had interacted with him at the church on prior occasions without incident. ${ }^{42}$

While the Cherfi and Kazemian cases might appear to suggest that sanctuary in Canada has become less successful than it was in the 1980s and 1990s, on closer inspection such a conclusion does not seem warranted. To appreciate why this is the case, it is important to understand that neither Cherfi nor Kazemian was ultimately returned to his country of origin.

In Kazemian's case, within two days of his arrest, which garnered national media attention, the Department of Citizenship and Immigration exercised its discretion to grant his prior request for Canadian Permanent Residence on humanitarian and compassionate grounds. Immigration officials, somewhat implausibly, claimed that the timing of the decision was not related to his arrest. ${ }^{43}$

In Cherfi's case, resolution was much longer in coming. When Cherfi was forcibly removed from sanctuary and deported to the United States he applied for US asylum based on risks of persecution he claimed to face in Algeria. US immigration officials initially denied his application. ${ }^{44}$ He then appealed this decision to the Board of Immigration Appeals (BIA). Fifteen months after he was first deported from Canada to the United States, the BIA announced its decision: the initial decision was overturned and Cherfi was granted refugee status in the United States. ${ }^{45}$ In other words, the BIA confirmed the legal argument made by the church that offered Cherfi sanctuary. That is to say, notwithstanding negative determinations within first instance refugee adjudication forums in both Canada and the United States, when given a meaningful opportunity to appeal these negative decisions, Cherfi was able to demonstrate that he did, in fact, meet the refugee definition.

\section{Legality and Canadian Sanctuary Incidents}

Though the Cherfi and Kazemian cases-the only two known instances where Canadian police have arrested migrants in sanctuary-do not necessarily indicate that sanctuary has become less successful in recent years, they do lead to the main issue that I would like to address regarding Canadian sanctuary practices, namely, that law plays a complex and contested role in these practices.

Cherfi's arrest and deportation generated significant public debate about sanctuary. ${ }^{46}$ Judy Sgro, then Minister of Citizenship and Immigration, further fanned the flames of this controversy when, some months later, she called on churches to cease providing sanctuary to unsuccessful refugee claimants. ${ }^{47}$ Sgro contended that sanctuary practices should be stopped because they violate Canadian law. As Sgro provocatively put it in the media, "Nobody is exempt from the law, no matter where you are." 48 Many Canadians, as shown by letters to the editor, ${ }^{49}$ editorials, ${ }^{50}$ and calls to national radio call-in shows, ${ }^{51}$ concurred with Sgro's views.

Church groups, however, immediately responded to Sgro's comments by insisting that they would continue to offer sanctuary. ${ }^{52}$ Moreover, many sanctuary supporters contested Sgro's simple characterization of sanctuary as unlawful, suggesting that the matter was more complicated. In particular, many noted that churches intervene only in cases where the Canadian government is itself in danger of breaching international law as a result of its failure to design a refugee determination system with adequate procedural safeguards to prevent refugees from being deported to face persecution. ${ }^{53}$ As a spokesperson for the United Church of Canada noted in the national media: "The only time a church will ever put itself in the awkward place of offering sanctuary to someone who requests it is because we understand that Canada ... is not living up to its international obligations." 54 Similarly, a press release prepared by an association of congregations providing sanctuary notes:

\footnotetext{
"The real problem we want to address today is not sanctuary, but the flawed refugee determination system that fails to protect some refugees," said Archbishop Andrew Hutchison ... [c]iting the lack of a merit-based appeal process in refugee determinations. ${ }^{55}$
}

(C) Sean Rehaag, 2009. This open-access work is licensed under a Creative Commons Attribution-NonCommercial 4.0 International License, which permits use, reproduction and distribution in any medium for non-commercial purposes, provided the original author(s) are credited and the original publication in Refuge: Canada's Journal on Refugees is cited. 
Other supporters of sanctuary, however, suggested that it is precisely because of their distance from Canadian state law that sanctuary practices are valuable and should be maintained. For example, in an op-ed piece in the National Post, Father Raymond de Souza wrote:

The custom of sanctuary is a vestige of an era when the absolute power of the state needed trimming. Our legal system today offers many protections and safeguards, but it is always good to be reminded there are places where the state does not go and where it does not assert its sovereignty. ${ }^{56}$

Or, as a caller to a national call-in radio show put it:

[Sanctuary] is the earliest form ... [of] civil disobedience ... of communities, small groups religiously affiliated or otherwise ... resist[ing] top-down applications of power ... When peaceful people stand up and break the law ... they almost always have very good reasons for doing so. And so the state should ... look at its own processes to see what is causing this civil disobedience. ${ }^{57}$

\section{Three Narratives about Law in Canadian Sanctuary \\ Practices}

Given the existence of these controversies over the legality of church sanctuary, it is not surprising that Randy Lippert, in his systemic study of Canadian sanctuary practices, concludes that law plays an important role for sanctuary providers. ${ }^{58}$ To assess how Canadian sanctuary providers understand the relation between sanctuary and law, Lippert draws on the work of critical legal scholars Patricia Ewick and Susan Silbey, who identify three distinct narratives about how individuals interact with the law. ${ }^{59}$ Lippert then examines how sanctuary providers draw on each of these narratives. ${ }^{60}$

In the first narrative, individuals are imagined to be "up against the law." That is to say, they experience the law as an oppressive force in their lives, a force that must be resisted through avoidance strategies because it is too powerful to be confronted directly. ${ }^{61}$ According to Lippert, sanctuary providers frequently deploy this narrative. More precisely, they often present sanctuary as an extra-legal means through which marginalized migrants may avoid coercive deportation that flows from what they consider to be arbitrary and oppressive immigration laws. From this perspective, sanctuary is a form of civil disobedience to purportedly unjust laws. ${ }^{62}$

In the second narrative, individuals are understood to be "before the 'higher' law." 63 Here, "law" is not limited to officially declared state legal norms. Instead, law is understood to be a majestic and rational force that "stands outside and above social life." ${ }^{64}$ According to Lippert, sanctuary providers resort to this narrative when they claim that the official refugee determination system produces results that not only are unjust, but also violate higher legal principles. Occasionally, the legal principles referred to are religious in nature-i.e. God's law, religious natural law, etc More frequently, however, the claim is that deportation to face human rights violations is a breach of international law. As a result, where the official refugee determination system fails to protect individuals who will be subject to human rights violations on deportation, churches may legitimately take measures to prevent deportation. In these circumstances, it is the state authorities-not the churches-who are at risk of violating the law. ${ }^{65}$

The third narrative involves individuals "(playing) with the law." ${ }^{\prime \prime}$ In this narrative, the law is imagined as a set of complex processes, each of which is fraught with error and subject to significant delays. Individuals encounter these processes and attempt to navigate them strategically. In other words, law is experienced as a kind of high-stakes game. According to Lippert, sanctuary providers demonstrate such an understanding of law when they assert that sanctuary aims not to undermine existing legal processes, but rather to delay deportation in order to provide migrants with extra time during which legal processes can run their course. The hope is that migrants will use this extra time to obtain more favourable outcomes. ${ }^{67}$

\section{Sanctuary and Canadian State Law}

While Lippert offers evidence to substantiate his claim that sanctuary providers deploy each of these three narratives, ${ }^{68}$ his discussion of the role of law in sanctuary omits what one would think to be a critical consideration: he does not offer an extended analysis of the legality of sanctuary practices under state law. In fact, although he repeatedly asserts that sanctuary is illegal, ${ }^{69}$ on only one occasion-in an endnote-does he briefly articulate the basis of its illegality. Here is that explanation in full:

Sanctuary is illegal under Canada's Immigration Act and Criminal Code because it involves aiding and abetting as well as conspiracy. Since at least 1976, the Immigration Act has prohibited aiding and abetting migrants subjected to deportation orders and has stipulated fines of up to $\mathrm{CDN} \$ 5,000$ and two years imprisonment. ${ }^{70}$

Now, to be fair, journalists, ${ }^{71}$ public officials, ${ }^{72}$ and even sanctuary providers ${ }^{73}$ do frequently contend, often without elaboration, that sanctuary practices violate Canadian state law. Moreover, Lippert's analysis of the role of law in sanctuary incidents aims primarily at understanding how sanctuary providers use and discuss law, rather than at inquiring into the validity - from the perspective of state law-of such 
uses and discussions. ${ }^{74}$ As a result, his decision not to offer an in-depth analysis of state law may be understandable. For our purposes, however, closer attention to the relevant provisions of state law that purport to render sanctuary illegal is warranted.

\section{The Legality of Taking Sanctuary}

There are two distinct questions to be asked regarding how state law may render sanctuary practices unlawful. The first relates to the lawfulness of taking sanctuary, and the second relates to the lawfulness of providing sanctuary.

With respect to the first question, whether it is lawful for migrants to take sanctuary, it must be recalled that migrants only enter sanctuary when they are vulnerable to removal from Canada. ${ }^{75}$ In principle, then, migrants in sanctuary will usually be in violation of an enforceable removal order. $^{76}$ Section $48(2)$ of the Immigration and Refugee Protection Act [IRPA] states that: "If a removal order is enforceable, the foreign national against whom it was made must leave Canada immediately." 77 Moreover, the IRPA's general offences provisions (s.124), makes the violation of s.48(2) an offence: "Every person commits an offence who ... contravenes a provision of this Act." 78 The penalties for this offence include a possible fine of $\$ 50,000$ and a term of imprisonment of up to two years. ${ }^{79}$

Of course, in order to commit an offence by remaining in Canada in breach of a removal order, the removal order in question must be legally valid. It is worth noting, however, that the validity of the removal order will frequently be contested in sanctuary incidents. As we have seen, most migrants in sanctuary are unsuccessful refugee claimants who contend that an error was made in their initial refugee determination. Indeed, the standard argument is not only that there was an error committed during the initial refugee claim, but also that, due to systemic procedural flaws in the refugee determination system-most notably the lack of an appeal-the error cannot be corrected through official channels. ${ }^{80}$ In such circumstances a removal order might be invalid under state law for a variety of reasons, including breaches of international law ${ }^{81}$ that has become part of Canadian law, ${ }^{82}$ breaches of constitutional law, ${ }^{83}$ or breaches of administrative law norms of procedural fairness. ${ }^{84}$

Lippert hints at such a possibility when he notes that sanctuary providers adopting the "before the (higher) law" narrative frequently make reference to international human rights law. ${ }^{85}$ It is important to keep in mind, however, that assertions about the invalidity of a removal order need not take the form of a "higher" law argument. That is to say, the contention is not necessarily that when a removal order complies with state-based immigration law but breaches international law, the latter (representing higher law) should trump the former. That would be a scenario of conflict of law between two distinct legal orders. Rather, the argument may simply be that the removal order is invalid under domestic law-possibly, but not necessarily, by virtue of the incorporation of international law into domestic law. This is not a conflict of law scenario, but rather a straightforward question of legal validity from the perspective of a single (statebased) legal order.

Of course, while migrants in sanctuary may contend that their removal orders are invalid due to breaches of Canadian state law, and thus that they themselves are not breaching Canadian state law by remaining in Canada, it is unlikely that such arguments would be persuasive in court. Indeed, those in sanctuary have usually already exhausted all avenues for judicially reviewing their negative refugee determinations as well as the subsequent immigration procedures culminating in their removal orders. ${ }^{86}$ Any available arguments regarding the legal invalidity of those procedures have, therefore, presumably already been rejected by courts by the time migrants enter sanctuary. ${ }^{87}$

To say that courts are unlikely to accept arguments regarding the invalidity of removal orders pertaining to migrants in sanctuary, however, does not mean that such arguments are unimportant to sanctuary practices. To the contrary, it is precisely in order to ensure that migrants can reasonably make such arguments that the church guidelines suggest that congregations provide sanctuary only to migrants who demonstrate that they qualify for refugee protection under Canadian state law, notwithstanding contrary findings in the official refugee determination system. ${ }^{88}$ In other words, one of the reasons congregations resort to sophisticated screening mechanisms is to ensure that sanctuary can be justified on the basis that the state has misapplied and misinterpreted state law in particular cases. Indeed, this helps to explain why sanctuary providers place so much focus on systemic procedural flaws in the refugee determination system, and, in particular, on the argument that misinterpretations and misapplications of state law in particular cases cannot currently be corrected because of the lack of an effective appeal mechanism. ${ }^{89}$ What this shows is that sanctuary is partly about individuals insisting that state institutions, including courts, do not have the final word on the interpretation of state law. Sanctuary practices are, to put this point in slightly different terms, premised on the notion that even the highest and most authoritative state institutions can-and sometimes do-get the law wrong.

In my view, then, in the event that migrants in sanctuary are charged with violating Canadian immigration law, and in particular with remaining in Canada in contravention of a removal order, courts are likely to dismiss arguments that

(C) Sean Rehaag, 2009. This open-access work is licensed under a Creative Commons Attribution-NonCommercial 4.0 International License, which permits use, reproduction and distribution in any medium for non-commercial purposes, provided the original author(s) are credited and the original publication in Refuge: Canada's Journal on Refugees is cited. 
the underlying removal order is itself invalid under domestic law. However, arguments regarding the legal invalidity of removal orders (as well as the legal invalidity of negative refugee determinations that lead to removal orders) under domestic state law remain central to Canadian sanctuary practices.

\section{The Legality of Offering Sanctuary}

With regard to the second question that must be posed when assessing the legality of sanctuary-whether those who provide sanctuary violate Canadian state law-the matter is even more complex.

There is one provision of Canadian immigration law ${ }^{90}$ that is most frequently cited as purportedly rendering sanctuary unlawful, s.131 of the IRPA. This section reads, in part:

Every person who knowingly ... aid or abets ... a person to contravene section ... 124, or who counsels a person to do so, commits an offence and is liable to the same penalty as that person. ${ }^{91}$

As we have seen, migrants in sanctuary arguably commit an offence under s.124 of the IRPA by remaining in Canada in violation of a removal order. ${ }^{92}$ Thus, to the extent that sanctuary providers (1) counsel, (2) aid, or (3) abet the commission of that offence, the IRPA renders sanctuary providers liable to the same punishment as the migrants themselves: up to two years in jail and a $\$ 50,000$ fine. ${ }^{93}$

Let us deal with counselling first. The Supreme Court has recently interpreted "counselling an offence" to mean "deliberate encouragement or active inducement of the commission of a[n] ... offence." 94 The Court has also noted that the types of behaviour covered by counselling include: advising, recommending, procuring, bringing about, soliciting, asking repeatedly for, seeking, inviting, making a request, petitioning, urging, instigating, or persuading. ${ }^{95}$ Now, it must be said that some sanctuary providers likely do counsel particular individuals to enter sanctuary and remain in Canada in violation of a removal order. Where they do so, they may be guilty of counselling the commission of an offence. Where, however, migrants take the initiative and decide to remain in Canada (whether in sanctuary or otherwise) in violation of a removal order without being deliberately encouraged or actively induced to do so, then sanctuary providers cannot be said to have counselled the commission of an offence. In other words, providing sanctuary does not necessarily entail counselling the commission of an offence. Rather, whether sanctuary providers engage in counselling the commission of an offence is a contingent, factually dependent matter.
Next, let us consider the immigration law provisions on aiding and abetting. Based on documents provided in response to an Access to Information Request, these provisions are at the heart of the legal theory according to which government officials apparently feel that sanctuary violates Canadian law. According to a document entitled "Avoiding Deportation by Claiming Sanctuary," prepared by the Department of Citizenship and Immigration (CIC):

It is an offence pursuant to IRPA to aid and abet a person to contravene the Immigration and Refugee Protection Act. In practice prosecution is discretionary and therefore churches which actively assist persons in evading removal have, to date not faced charges. ${ }^{96}$

Similarly, a second document entitled "Sanctuary in Churches," also prepared by CIC, states: "Its [sic] is an offence pursuant to IRPA ... to aid and abet a person to contravene the Immigration and Refugee Protection Act." 97

In what sense, then, might providing sanctuary constitute aiding and abetting the offence of remaining in Canada in violation of a removal order? Because no sanctuary providers in Canada have ever been charged under these provisions, there is no case law to assist us in interpreting the provisions in this specific context. However, even setting aside the arguments regarding the validity of the underlying removal orders in sanctuary cases, it is not obvious that Canadian sanctuary providers in fact aid and abet the commission of an offence.

In examining whether sanctuary providers engage in aiding and abetting, the first step is to notice that while the terms are often used in tandem, they do, in fact, represent distinct offences. As Justice Cory put it in R. v. Greyeyes:

The terms "aiding" and "abetting" are often used together in the context of determining whether persons are parties to an offence. Although the meanings of these terms are similar, they are separate concepts ... To aid ... means to assist or help the actor ... To abet ... includes encouraging, instigating, promoting or procuring the crime to be committed..$^{98}$

Let us, therefore, consider "aiding" and "abetting" in turn.

With respect to "aiding," it is important to recall the distinction between "concealment" and "exposure" strategies in sanctuary practices. ${ }^{99}$ Where a church conceals a person who is subject to a valid removal order so as to avoid detection by authorities, it seems clear that they are engaged in the offence of "aiding." However, where churches publicly declare that they have provided sanctuary to a particular migrant, adding that they will not take any steps to resist official enforcement activities, then it is not clear how they

(C) Sean Rehaag, 2009. This open-access work is licensed under a Creative Commons Attribution-NonCommercial 4.0 International License, which permits use, reproduction and distribution in any medium for non-commercial purposes, provided the original author(s) are credited and the original publication in Refuge: Canada's Journal on Refugees is cited. 
are "aiding" the migrant to commit the offence of remaining in Canada in violation of a removal order. This is significant because many churches take active steps not only to inform state officials about their decision to accord sanctuary, but also to indicate that they have no intention of interfering with enforcement measures. The following comments by a sanctuary provider are typical in this regard:

The decision was made right from the outset that this church would never be locked so that the authorities could never say that they were stopped from coming into the church. And we went on public record ... that the church was always open and we were not going to stand in the way of the law. ${ }^{100}$

Other sanctuary providers echoed such an approach:

We called the immigration people and said, "If you want to come in at any time, we will show you around ..." If Immigration decided that they wanted to come pick [the person in sanctuary] up, they [can] just tell us. We'll hold the door [open] ... We aren't going to stand in the way of an actual apprehension, but we are also going to grant her sanctuary." 101

It is, moreover, important to note that, by virtue of legislation repealing all recognition of sanctuary as a matter of state law in the seventeenth century, ${ }^{102}$ the fact that migrants may be located inside churches in no way diminishes the legal authority of Canadian police or immigration officials to enforce removal orders against them. If authorities choose not to enforce removal orders against migrants they know to be taking sanctuary inside churches, that decision is purely political (i.e. the government wishes to avoid the negative political reaction that media accounts of the use of police force inside a church inevitably engenders). Merely increasing the political cost of enforcing state law should not be interpreted to constitute "aiding"; otherwise anyone who seeks to bring public attention to unpopular enforcement measures would be guilty of "aiding" the commission of an offence.

It is worth noting one other sense in which sanctuary providers might be said to commit the offence of "aiding," namely by sheltering, feeding, and providing other services to individuals in sanctuary. This reasoning would run as follows: when people knowingly assist migrants subject to removal orders by providing them with food, shelter, or other services, they facilitate those migrants' ongoing violations of the removal orders.

There are, however, two problems with such reasoning. The first is that Canadian legislation does not explicitly prohibit "harbouring" individuals who are unlawfully present in Canada. ${ }^{103}$ The equivalent US legislation, in contrast, prohibits not only "aiding" 104 but also "harboring"105 aliens not lawfully entitled to enter or remain in the country. Indeed, in the 1980 s several sanctuary providers were convicted of harbouring aliens unlawfully present in the US. ${ }^{106}$ Moreover, as in the US, harbouring is recognized as distinct from "aiding" in Canadian law. For example, although the Canadian Criminal Code contains general provisions on "aiding," 107 it also explicitly criminalizes "harbouring" those who commit specific crimes. ${ }^{108}$

There is, therefore, a distinction between "aiding" and "harbouring" under Canadian law. Because Canadian law does not explicitly prohibit harbouring migrants who are unlawfully present in the country, in my view, merely providing shelter, food, and other services to such migrants should not be considered "aiding" the commission of an offence.

The second reason why "aiding" should not be interpreted to cover providing food, shelter, and other services to migrants subject to a removal order is that such an interpretation would cast the net far too widely. Indeed, this interpretation would criminalize the work of organizations that run shelters for women without legal immigration status who are victims of domestic violence, legal clinics that offer services to undocumented migrants, schools that educate children who are not lawfully in the country, hospitals that provide emergency medical treatment to individuals without status, and even police services with "don't ask, don't tell” policies regarding immigration status. By providing services to migrants unlawfully present in Canada, such organizations arguably "aid" migrants to remain in Canada unlawfully, and thus could, in principle, be covered by the broadest possible reading of the "aiding" provisions. However, if Parliament intended to criminalize all humanitarian assistance provided to migrants who are in the country unlawfully, surely they would have done so explicitly. ${ }^{109}$

Rather than adopting an overly broad understanding of "aiding," a more reasonable approach would be to restrict "aiding" in this context to scenarios where the accused materially assists migrants to avoid detection or otherwise evade the enforcement of a valid removal order. In applying this restricted understanding of "aiding," it is important to recall that when churches offering sanctuary engage solely in exposure strategies, they, by definition, do not assist migrants avoid detection. Moreover, while they may increase the political cost of enforcing removal orders, they often nonetheless assert in advance that they will not physically interfere with the enforcement of removal orders. In my view, then, to the extent that sanctuary providers engage solely in exposure strategies, ${ }^{110}$ they should not be understood to be "aiding" the commission of the offence com-

(C) Sean Rehaag, 2009. This open-access work is licensed under a Creative Commons Attribution-NonCommercial 4.0 International License, which permits use, reproduction and distribution in any medium for non-commercial purposes, provided the original author(s) are credited and the original publication in Refuge: Canada's Journal on Refugees is cited. 
mitted by migrants who remain in Canada in violation of a valid removal order.

So much for "aiding," but what about the third possible grounds for the purported illegality of providing sanctuary, namely the immigration law provisions on "abetting"? Abetting in Canadian law is similar to the criminal law provisions on counselling an offence, in that abetting involves encouraging someone to commit an offence. As Justice Cory noted in R. v. Greyeyes, the Criminal Code provides that

any person who abets any person in committing an offence is a party to that offence. In order to secure a conviction, the Crown must prove not only that the accused encouraged the principal with his or her words or acts, but also that the accused intended to do so. ${ }^{111}$

Similarly, in a frequently cited passage, the Alberta Supreme Court explains that, to secure a conviction on the charge of abetting, the accused

must intend that the words or acts will encourage the principal. The criminal law is concerned with acts or words that are done or uttered with the intent or for the purpose of counselling, encouraging, instigating or promoting the commission of the acts by the principal actor. Accordingly before an accused person can be convicted the Crown must prove, beyond a reasonable doubt, both the words of encouragement and the intention of the appellant to so encourage. ${ }^{112}$

In other words, whether sanctuary providers engage in abetting rests on whether they encourage or instigate the commission of the principal offence (i.e. the migrant remaining in Canada in violation of a valid removal order).

As with my discussion of the offence of counselling above, whether sanctuary providers engage in abetting is a factually contingent matter. Some sanctuary providers likely do encourage migrants to remain in Canada in violation of a valid removal order. In other cases, however, migrants requesting sanctuary fully intend to remain in the country regardless of whether they succeed in obtaining sanctuary. If they are unable to obtain sanctuary, they will remain underground and try to avoid detection by immigration authorities. If, on the other hand, they succeed in obtaining sanctuary they will publicly move into the church and hope that the state chooses not to enforce the removal order against them. In such circumstances, it is unclear in what sense church communities that accede to requests for sanctuary can be said to "encourage" the commission of the principal offence of remaining in Canada in violation of a removal order.
Moreover, as with a broad interpretation of "aiding," there is a serious danger in adopting an expansive reading of "abetting" that would cover the kind of moral and political support that church communities offer migrants in sanctuary. Merely offering moral and political support to people who violate a valid law-rather than encouraging them to break the law-should not constitute "abetting" lest the net be too widely cast. In fact, an expansive interpretation of "abetting" would catch a significant number of influential public officials and community leaders, who regularly provide political assistance to migrants who are in Canada in violation of removal orders. Indeed, several sitting members of Parliament have offered political support to migrants in sanctuary, and would thus be vulnerable to prosecution under an excessively expansive understanding of "abetting." 113

In my view, the best interpretation of "abetting" in the context of church sanctuary incidents is a restricted reading that would cover only circumstances where sanctuary providers actively encourage migrants to remain in Canada in violation of a valid removal order. Whether particular sanctuary providers in fact do so is a factually contingent matter; the mere accession to a request for sanctuary by a migrant should not, on its own, be understood to constitute "abetting."

\section{The Final Word on Legality and Canadian Sanctuary} Practices

All of this is to say, then, that those asserting that Canadian sanctuary practices are clearly illegal have not accorded sufficient attention to the relevant provisions of state law. A close assessment reveals that individuals taking sanctuary may appear to be in violation of a removal order, but churches providing sanctuary take measures to ensure that they can at least plausibly argue that these removal orders are legally invalid under state law-even if the state refuses to recognize this legal invalidity. Moreover, even if the removal orders in question are legally valid, and it is thus unlawful for individual migrants to remain in the country by taking sanctuary, it is still not at all obvious that faithbased communities publicly providing sanctuary necessarily violate state law.

In the end, while there is admittedly room for disagreement regarding the legality of Canadian sanctuary practices under state law, what is certain is that such practices involve a fascinating set of legal claims. In particular, sanctuary practices raise competing jurisdictional claims between multiple, partly overlapping, legal systems (i.e. domestic law, international law, ecclesiastic law). They also involve differing interpretations about how those multiple legal systems intersect, and what to do in the event of conflict-although

(C) Sean Rehaag, 2009. This open-access work is licensed under a Creative Commons Attribution-NonCommercial 4.0 International License, which permits use, reproduction and distribution in any medium for non-commercial purposes, provided the original author(s) are credited and the original publication in Refuge: Canada's Journal on Refugees is cited. 
I hasten to add that one should not be too quick to presume that there are necessarily conflicts. Sanctuary practices also raise questions about who has the final word on interpreting norms within state-based legal systems, whether state institutions or those who are subject to them.

What I want to emphasize in all of this is that assessing the claims and questions raised by sanctuary practices requires close attention not just to broad political arguments, not just, that is to say, to how sanctuary is discussed and debated. Rather, close attention must also be paid to the precise legal norms that inhere in the legal systems at play in sanctuary incidents. Such close attention offers an intriguing picture of legal systems not only conflicting, but also interacting, and, at times, even mimicking one another in order to publicly highlight the internal inconsistencies in the opposing legal decision-making process.

\section{Conclusion}

Despite its formal abolishment as a matter of state law in the sixteenth and seventeenth centuries, church sanctuary continues to be practiced in Canada to this day. These practices have been surprisingly effective, not just in terms of preventing the de facto deportation of individual migrants who allege a fear of persecution (and in securing legal immigration status for such individuals), but also in terms of placing significant pressure on government actors to introduce policy changes that would bring the official refugee determination system into compliance with both domestic and international law.

Law plays a complex and controversial role in contemporary Canadian sanctuary practices. While public debates about the legitimacy of church sanctuary frequently turn on the issue of whether sanctuary is a justifiable form of civil disobedience to purportedly unjust laws, framing sanctuary in such terms is problematic on several levels. In particular, many of those involved in church sanctuary practices do not accept that these practices in fact violate state law, and thus that they can accurately be characterized as civil disobedience.

There are two distinct senses in which we can understand these arguments. The first, which relates to whether the state is acting lawfully in seeking to deport particular migrants, is especially relevant when those seeking sanctuary claim they face a risk of persecution abroad, notwithstanding a contrary finding in the official refugee determination system. Advocates of church sanctuary in such circumstances frequently suggest that deporting these individuals is unlawful, and that when faith-based communities take measures to prevent such unlawful deportations they are actually enhancing respect for the rule of law. Interestingly, these arguments usually involve procedural rather than substantive complaints about the refugee determination system. That is to say, sanctuary advocates suggest that, due to systemic procedural flaws in the Canadian refugee determination system, including the lack of an effective appeal mechanism to correct false negative determinations, some who do in fact qualify for refugee protection under state law are not recognized as such. Churches then suggest that it is only because of these procedural flaws that they must step in to prevent the unlawful deportation of such "genuine" refugees. In order to be in a position to plausibly make such assertions, churches are placed in the curious position of mimicking the decision-making processes mandated by state law in order to determine whether those seeking sanctuary do, in principle, qualify for refugee protection.

The second sense in which sanctuary providers may claim that they do not breach state law concedes that migrants in sanctuary themselves violate immigration law. They may go on to argue, however, that publicly providing sanctuary to such individuals is not unlawful because, so long as sanctuary providers do not conceal migrants from authorities and do not resist enforcement activities, they do not legally interfere with the enforcement of state immigration law. On this view, although the state may choose not to undertake deportation measures against individuals known to be inside churches because it wishes to avoid the political consequences that such measures would bring, churches offering sanctuary do not impede these deportation measures in a manner cognizable by state law. Of course, where sanctuary practices involve concealing migrants from detection by immigration officials, such reasoning would not apply.

Taken together, the argument that Canadian government officials offered in response to the incident involving Mohamed Cherfi (i.e. that churches should cease providing sanctuary because "no one is above the law") is based on an excessively narrow view of the legal claims involved. To be sure, there are rule-of-law arguments in favour of the notion that churches should not be allowed to exempt themselves from the application of Canadian immigration law. Moreover, it must be acknowledged that some Canadian sanctuary providers insist that sanctuary practices are effective precisely because they involve a deliberate and politically charged breach of purportedly unjust Canadian laws (i.e. civil disobedience). However, there are also plausible rule-of-law arguments in favour of sanctuary practices. Firstly, it is not clear that faith-based communities actually breach state law when they provide sanctuary to those who request it. Secondly, and in my view more importantly, sanctuary practices may actually uphold both Canadian and international law by establishing a de facto appeal mechanism to catch errors in the procedurally flawed official refugee determination system, thereby preventing Canada from

(C) Sean Rehaag, 2009. This open-access work is licensed under a Creative Commons Attribution-NonCommercial 4.0 International License, which permits use, reproduction and distribution in any medium for non-commercial purposes, provided the original author(s) are credited and the original publication in Refuge: Canada's Journal on Refugees is cited. 
unlawfully deporting refugees to countries where they face persecution.

\section{Notes}

1. There are also sanctuary traditions in several non-Christian religions. For discussions of sanctuary in Islamic law, for example, see Ghassan Maarouf Arnaout, Asylum in the Arab-Islamic Tradition (Geneva: UNHCR, 1987); Khadija Elmadmad, Asile et réfugiés dans les pays afro-arabes (Casablanca: EDDIF, 2002).

2. For discussions of the history of sanctuary, see Kent Rigsby, Asylia: Territorial Inviolability in the Hellenistic World (Vancouver: University of British Columbia Press, 1996); Jan Hallebeek, "Church Asylum in Late Antiquity: Concession by the Emperor or Competence of the Church?" in E.C. Coppens, ed., Secundum Ius: Opstellen aangeboden aan prof. mr. P.L. Nève (Nijmegen, 2005) at 163-182, online: <http:// dare.ubvu.vu.nl/bitstream/1871/9006/1/church+asylum. pdf $>$; J. Charles Cox, The Sanctuaries \& Sanctuary Seekers of Mediaeval England (London: George Allen \& Sons, 1911); Jorge Carro, "Sanctuary: The Resurgence of an Age-Old Right or a Dangerous Misinterpretation of an Abandoned Ancient Privilege?" (1986) 54 U. Cin. L. Rev. 747; Matthew Price, "Politics or Humanitarianism? Recovering the Political Roots of Asylum" (2005) 19 Geo. Immigr. L.J. 277.

3. I use the term "state law" throughout this article to refer to official law emanating from state-based legal orders. Some readers may find this unusual, given that "law" is usually used without a qualifier to refer to official law emanating from state-based legal orders. However, the qualifier is necessary because this article deals in part with norms emanating from non-state institutions that seem to share certain legal properties (i.e. canon law). Nonetheless, for the limited purposes of this article, little turns on whether non-state norms can properly be termed "law," and readers who are uncomfortable with the concept of non-state law should feel free to adopt some other term. For a general discussion of when non-state institutions may produce what some scholars view as legal norms, see Boaventura de Sousa Santos, Toward a New Legal Common Sense, $2^{\text {nd }}$ ed. (London: Butterworths, 2002) (see especially at 89-98).

4. For example, sanctuary was abolished in France as a matter of state law in 1515. Price, supra note 2 at 291. In the UK, sanctuary was abolished in 1623. Statute 21, James I, Ch. 28 s.7 (1623), cited in Kathleen Villarruel, "The Underground Railroad and the Sanctuary Movement: A Comparison of History, Litigation, and Values" (1987) 60 Southern Calif. L. Rev. 1429 at 1433. See also Carro, supra note 2 at 766.

5. Susan Coutin, "Smugglers or Samaritans in Tuscon, Arizona: Producing and Contesting Legal Truth" (1995) 22 American Ethnologist 549 [Coutin, "Samaritans"]; Phillippe Ségur, "L'asile religieux dans la modernité" (1997) 53 Migrations Société 61; Verena Mittermaier, Church Asylum in Germany (Berlin: German Ecumenical Committee on Church Asylum, 2007), online: <http://www.kirchenasyl.de/1_start/English/Church\%20asylum\%20in\%20 Germany.pdf>.

6. Only two reported sanctuary incidents in Canada, both of which occurred within the last two years, have involved non-Christian faith-based communities. The first incident involved a Montreal mosque, and the second involved a Hindu temple in Vancouver. Lisa-Marie Gervais, "L'imam Jaziri senfermera dans sa mosquée pour éviter dêtre expulsé" Le Devoir (16 December 2006) A4; Jane Armstrong, "Refugee seeks asylum in Sikh temple" The Globe and Mail (9 July 2007) S1.

7. For a review of Canadian sanctuary practices see Randy Lippert, Sanctuary, Sovereignty, Sacrifice: Canadian Sanctuary Incidents, Power, and Law (Vancouver: University of British Columbia Press, 2005) [Lippert, Sanctuary]; David Matas, "Canadian Sanctuary" (1988) 8:2 Refuge 14; Charles Stastny \& Gabrielle Tyrnauer, "Sanctuary in Canada" in Vaughan Robinson, ed., The International Refugee Crisis: British and Canadian Responses (London: Macmillan, 1993).

8. Lippert, Sanctuary, supra note 7.).

9. Ibid. at 15 .

10. Ibid.

11. Ibid.

12. Ibid. at 1 .

13. Ibid. at $35-37$.

14. Ibid. at 37 .

15. Ibid. at 38 .

16. Ibid. at 40. In one case, however, the police arrested migrants taking sanctuary in a self-declared "church" that lacked official recognition. Ibid. at 40, n96.

17. Ibid. at 40 .

18. Ibid. at 40-41. The authority to make exceptions from the regular immigration procedures flows from Immigration and Refugee Protection Act, S.C. 2001, c. 27 [IRPA], s.25.

19. Lippert, Sanctuary, supra note 7 at $40-41$.

20. The average duration of sanctuary incidents was five months, but a significant minority lasted over a year. Ibid. at 27 .

21. According to information obtained from the IRB through an Access to Information Request, there were 8,015 applications for leave to judicially review IRB refugee determinations in 2003. Leave was granted in 449 (5.6 per cent) of these applications, and judicial review was ultimately successful in only 142 cases ( 1.8 per cent). IRB, Letter in Response to an Access to Information Request by the Author (2 May 2008) IRB File\# A-2008-00001 (on file with author). For similar figures for 2001, see John Frecker, Immigration and Refugee Legal Aid Cost Drivers: Final Report (Ottawa: Department of Justice, 2002) at 84.

22. For example, Pre-Removal Risk Assessments, a final opportunity immediately prior to deportation to present new evidence that one faces a risk in one's home country, have a 
success rate of 3 per cent in recent years. Benjamin Dolin \& Margaret Young, Background Paper: Canada's Immigration Program (Ottawa: Parliamentary Information and Research Service, 2004) BP190E, at 16.

23. See generally Lippert, Sanctuary, supra note 7 at 68-75.

24. Michelle MacAfee, "Canadian churches follow Old Testament tradition in giving haven to refugees" (10 August 2003) Canadian Press Newswire (LEXIS).

25. United Church of Canada, Sanctuary for Refugees?: A Guide for Congregations (Toronto: United Church of Canada, 2004).

26. 189 U.N.T.S. 137 (adopted 28 July 1951; entered into force 22 April 1954).

27. United Church of Canada, supra note 25 at 7.

28. See, for example, Presbyterian Church in Canada, Sanctuary: A Statement and Guidelines for Congregations (2006) Report Presented to the $132^{\text {nd }}$ General Assembly, online: <http://www.presbyterian.ca/justice/reports/0506overture14-sanctuary.pdf $>$ at 12 .

29. See text accompanying notes 17 and 18.

30. Lippert, Sanctuary, supra note 7 at 27.

31. See e.g. Steve Lambert, "Churches protect refugee claimants" The Toronto Star (27 November 2006) C11 (“There are probably eight to 10 different ways of (appealing) a decision once it's made, said Mary Jo Leddy of the Ontario Sanctuary Coalition. 'But the sum of all of them doesn't equal a really serious appeal on the merits"'); Ingrid Peritz, "Deportation orders stayed in two sanctuary cases" The Globe and Mail (15 December 2004) A15 ("If there were an actual appeal mechanism, most of these cases wouldn't have to consider sanctuary', said Montreal lawyer Rick Goldman"); Maria Jiménez, "Historic crypt becomes sanctuary for failed refugee claimant" The Globe and Mail (25 September 2004) A6 ("Mary Corkery, executive director of KAIROS, an ecumenical social justice organization representing 11 Canadian churches and church organizations, [said] ... 'there is ... an urgent issue at stake: the lack of merit-based appeals for refugees"').

32. IRPA, supra note 18 , ss.110-111 \& 171 .

33. Among the provisions that were brought into force was one that reduced the number of adjudicators at refugee hearings. The prior practice was for two adjudicators to hear refugee claims, only one of whom needed to be persuaded in order for the claimant to receive refugee protection. The current legislation, however, makes single-adjudicator hearings the standard practice. Ibid., s.63.

34. Order Fixing June 28, 2002 as the Date of the Coming into Force of Certain Provisions of the Act, SI/2002-97, C. Gaz. 1997.II.1637.

35. United Church of Canada, supra note 25 at 5.

36. Interfaith Sanctuary Coalition, "Why do People Turn to Sanctuary?" (9 October 2003), online: <http://www.ccrweb.ca/whysanctuary.htm>.

37. See e.g. Inter-American Commission on Human Rights, "Report on the Situation of Human Rights of Asylum
Seekers Within the Canadian Refugee Determination System" (28 Feb 2000) OEA/Ser.L/V/II.106; Canadian Council for Refugees, "Refugee Appeal Division Backgrounder" (December 2006), online: <http://www. ccrweb.ca/RADbackgrounder.pdf $>$; Amnesty International Canada, "Canada: Refugees-No Recourse to Fair Appeal," online: <http://www.amnesty.ca/take_action/actions/canada_fair_appeal.php $>$.

38. Bill C-280, An Act to Amend the Immigration and Refugee Protection Act (coming into force of sections 110, 111 and 171), $1^{\text {st }}$ Sess., $39^{\text {th }}$ Parl., 2007 (as passed by the House of Commons 30 May 2007).

39. See e.g. House of Commons Debates, $39^{\text {th }}$ Parliament, $1^{\text {st }}$ Session, No.098 (29 January 2007) at 1105 (Nicole Demers); House of Commons Debates, $39^{\text {th }}$ Parliament, $1^{\text {st }}$ Session, no. 098 (29 January 2007) at 1140-1150 (Bill Siksay); House of Commons Debates, 39th Parliament, $1^{\text {st }}$ Session, No.122 (2 March 2007) at 1355 (Paul Dewar); House of Commons Debates, $38^{\text {th }}$ Parliament, $1^{\text {st }}$ Session, no. 010 (18 October 2004) at 1420 (Meili Faille); House of Commons Debates, $37^{\text {th }}$ Parliament, $3^{\text {rd }}$ Session, no. 014 (19 February 2004) at 1450 (Madeleine Dalphon-Guiral).

40. Cherfi was also subject to an outstanding warrant for allegedly violating bail conditions imposed in relation to a minor altercation at a public demonstration. Donna Sinclair, "The Cherfi arrest: Sanctuary violated" in The United Church Observer, online ed. (April 2004), online: <http:// www.ucobserver.org/archives/apr04_nation.shtml>.

41. Sinclair, supra note 40; Lippert, Sanctuary, supra note 7 at 166ff; Isabelle Porter, "Le Canada expulse le militant algérien Mohamed Cherf" Le Devoir (6 March 2004) A5.

42. Petti Fong, "Iranian refugee granted asylum" The Globe and Mail (20 February 2007) A12. See also "Iranian refugee Amir Kazemian to be allowed to remain in Canada" Diocese of New Westminster News (14 March 2007), online: $<$ http://www.vancouver.anglican.ca/News/tabid/27/ctl/ ViewArticle/ArticleId/450/mid/486/Default.aspx $>$.

43. Ibid.

44. Ingrid Peritz, "Algerian arrested in church denied asylum in U.S." The Globe and Mail (23 October 2004) A24.

45. Isabelle Porter, "Les États-Unis donnent raison à Cherfi" Le Devoir (3 June 2004) A4 [Porter, "Cherfi"].

46. See e.g. Louise Boivin, " 100 demonstrate for deported man" The Montreal Gazette (7 March 2004) A5; Louise-Maude Soucy, "Le mouvement d'appui à Cherfi prend de l'ampleur" Le Devoir (10 March 2004) A5; "Refugee claimant's supporters demand his return from U.S." The Toronto Star (10 March 2004) A7; Bill Power, "Quebec eviction worries Halifax woman" The [Halifax] Chronicle-Herald (11 March 2004) B1; Maxime Bergeron, "Les défenseurs de Cherfi exigent une enquête publique" La Presse (11 March 2004) A6; Michel Vastel, "Ça sest passé au Canada ... et à Québec" Le Soleil (11 March 2004) A17; Peter McKnight, "Yes, the violation of sanctuary is a big deal" The Vancouver Sun $(22$ March 2004) A8.

(C) Sean Rehaag, 2009. This open-access work is licensed under a Creative Commons Attribution-NonCommercial 4.0 International License, which permits use, reproduction and distribution in any medium for non-commercial purposes, provided the original author(s) are credited and the original publication in Refuge: Canada's Journal on Refugees is cited. 
47. Jim Bronskill, "Sgro to urge churches to stop practice of harbouring refugee claimants" The Globe and Mail (26 July 2004) A4.

48. Ibid.

49. See e.g. Allan Perry, "Churches should butt out," Letter to the Editor, The Montreal Gazette (3 August 2004) A14; Steven Taylor, "Scrap sanctuary," Letter to the Editor, The Globe and Mail (11 August 2004) A12.

50. See e.g. Editorial Board, "Churches no place for refugee appeals" The Edmonton Journal (27 July 2004) A12; James Bissett, "Forget churches: Reform the refugee system" The National Post (28 July 2004) A19 ("The Minister is right, of course: Churches have no business meddling in areas where they have no expertise or jurisdiction").

51. "Is Church Sanctuary Outdated," Cross Country Checkup, CBC Radio 1 (1 August 2004), online: <http://www.cbc.ca/ checkup/archives04.html> [Cross Country Checkup]:

David: "Church sanctuary is ... flat out illegal ... I'm outraged that my church ... is looking at sanctuary."

John: "Religious groups should not be above the law."

Ian: "[Sanctuary] fundamentally attacks two of our basic concepts of how we govern ourselves. One is the rule of law, and the other is the separation of church and state."

52. Jennifer Chen, "Churches will give refugees sanctuary until 'flawed' system fixed, leaders say" The Ottawa Citizen (27 July 2004) D3; Nicholas Kohler, "Churches want dialogue with Sgro: Will continue to offer sanctuary to refugees" The Montreal Gazette (27 July 2004).

53. See e.g. Robert Fleury, "Le droit d'asile des réfugiés" Le Soleil (29 July 2004) A15; Sean Rehaag, "No one is above the law on refugees" The Toronto Star (30 July 2004) A19; Catherine Dauvergne, "Why Judy Sgro is just plain wrong" The Globe and Mail (2 August 2004) A11; Mitchell Goldberg, "Why Sanctuary is Necessary" The Montreal Gazette (20 August 2004) A21.

54. Cited in Editorial Board, "Fix the system, leave churches alone" The Toronto Star (3 August 2004) A14.

55. KAIROS, "Refugees and Sanctuary in Canada: The Churches Respond," News Release (4 August 2004), online: $<$ http://www.kairoscanada.org/e/media/press/prRefugeesSanctuary040804.asp >.

56. Father Raymond de Souza, "No place left to hide: With the end of sanctuary, the state will be everywhere" The National Post (27 July 2004).

57. Cross Country Checkup, supra note 51 (Craig).

58. Lippert, Sanctuary, supra note 7 at 141-164.

59. Patricia Ewick \& Susan Silbey, Common Place of Law: Stories from Everyday Life (Chicago: University of Chicago Press, 1998), cited in Lippert, Sanctuary, supra note 7 at 141.

60. Lippert, Sanctuary, supra note 7 at 141.

61. Ibid.

62. Ibid. at $143-150$.

63. Ibid. at 150.

64. Ibid. at 141 .

65. Ibid. at $150-154$.
66. Ibid. at 141 .

67. Ibid. at $154-162$.

68. Ibid. at $143-162$.

69. Ibid. at 146, 150. See also Randy Lippert, "Sanctuary Practices, Rationalities, and Sovereignties" (2004) 29 Alternatives 535 at 548; Randy Lippert, "Rethinking Sanctuary: The Canadian Context, 1983-2003” (2005) 39 International Migration Review 381 at 398.

70. Lippert, Sanctuary, supra note 7 at 146, n.24.

71. Block, "Sanctuary and the defiant churches" Maclean's (30 January 1984) 43, cited in Ibid. at 146, n.24.

72. Jim Bronskill, "Sanctuary is 'breaking the law': Government memo says churches wrong to harbour refugees facing deportation" The Toronto Star (7 March 2005) A13.

73. Lippert, Sanctuary, supra note 7 at 146, n.24 \& 149. See also, United Church of Canada, supra note 25 at 6, 12 \& 20-24; Presbyterian Church in Canada, supra note 26 at 8.

74. This is a consequence of the "discourse analysis" methodology that Lippert adopts. Lippert, Sanctuary, supra note 7 at 10 .

75. This is built into Lippert's definition of sanctuary. See text accompanying note 10 .

76. For details regarding when removal orders come into force, see IRPA, supra note 18, s.49.

77. Ibid., s.48(2).

78. Ibid., s.124(1).

79. Ibid., s.125.

80. See text accompanying notes 52-54.

81. Under international refugee law, the prohibition on deportation to face persecution applies to all those who meet the refugee definition, not just to individuals whom states recognize as meeting the refugee definition. James Hathaway, The Rights of Refugees under International law (Cambridge: Cambridge University Press, 2005) at 158 (see especially n.17). As a result, it breaches international refugee law to deport a person who meets the refugee definition, but who was not recognized as such because of errors during the refugee determination process.

82. Canada's immigration legislation contains an interpretive clause that requires the legislation to be applied and interpreted in compliance with Canada's international legal obligations. IRPA, supra note 18, s.3(3)f.

83. Deportation in circumstance where a person may face a risk of persecution implicates the constitutional right to life, liberty, and the security of the person. Singh v. Minister of Employment and Immigration, [1985] 1 S.C.R. 177.

84. Administrative decisions that have serious impacts on people's lives are subject to heightened norms of procedural fairness. Baker v. Canada (Minister of Citizenship and Immigration), [1999] 2 S.C.R. 817.

85. See text accompanying notes $65 \& 66$.

86. Indeed, guidelines prepared by several denominations suggest that congregations should verify that all administrative and legal recourses have been exhausted prior to granting

(C) Sean Rehaag, 2009. This open-access work is licensed under a Creative Commons Attribution-NonCommercial 4.0 International License, which permits use, reproduction and distribution in any medium for non-commercial purposes, provided the original author(s) are credited and the original publication in Refuge: Canada's Journal on Refugees is cited. 
sanctuary. United Church of Canada, supra note 25 at 7; Presbyterian Church in Canada, supra note 28 at 12.

87. The rules regarding judicial review, however, complicate the matter. On the one hand, it is possible to apply to the Federal Court for leave to judicially review virtually any decision made by immigration officials. IRPA, supra note 18 , s.72-74. In other words, in principle, migrants facing removal have legal forums in which to contest the legal validity of both their refugee determinations and their removal orders. On the other hand, however, the opportunities to challenge the legal validity of decisions made in the immigration and refugee law setting are more restricted than in other areas of law. For example, Federal Court firstinstance decisions relating to judicial review in this setting cannot be appealed unless the judge at first instance certifies that a "serious question of general importance" is raised in the case. IRPA, supra note 18, s.74(d).

88. See text accompanying notes 25-28.

89. See text accompanying notes $35-36$.

90. In addition to immigration law, there are criminal law provisions which might be relevant. Most notably, the Canadian Criminal Code prohibits wilful obstruction (i.e. interfering with a police officer in the course of his or her duties). Criminal Code, R.S.C. 1985, c. C-46, s.129. However, as we will see below, because there is no legal impediment to police officers entering a church it is not clear in what way a church offering sanctuary actually interferes with a police officer unless some additional steps are taken (e.g. concealing the individual in sanctuary or physically preventing police officers from entering the church). See notes 99-109 (and accompanying text).

91. IRPA, supra note 18, s.131 (emphasis added).

92. See text accompanying notes $75-89$.

93. IRPA, supra note 18, s.124(1)(a).

94. R. v. Hamilton, 2005 SCC 47, [2005] 2 S.C.R. 432 at 29.

95. Ibid. at $21-23$

96. Citizenship and Immigration Canada, Letter in response to an Access to Information Request by the author (8 June 2005) CIC File\#: A-2004-02972/aa (on file with author) at 41.

97. Ibid. at 114 .

98. [1997] 2 S.C.R. 825 at 26 (per Cory J).

99. See text accompanying notes 9-10.

100. Lippert, Sanctuary, supra note 7 at 146.

101. Ibid. (emphasis added).
102. See note 4 (and accompanying text).

103. The only Canadian immigration law provision explicitly addressing "harbouring" is found in the section of the IRPA dealing with human trafficking, a context that is not generally relevant to sanctuary incidents. IRPA, supra note 18 , s.118.

104. 18 USCS $\$ 2$.

105.8 U.S.C. $\$ 1324$.

106. United States v. Aguilar, 883 F.2d $662\left(9^{\text {th }}\right.$ Cir. 1989) at 667.

107. Criminal Code, supra note 89, s.21(1)(b) \& (c).

108. Ibid., s.83.23.

109. In doing so they would be following in the footsteps of the US House of Representatives, which recently tried-and failed-to criminalize humanitarian assistance provided to unlawfully present aliens. U.S., Bill H.R.4437, Border Protection, Antiterrorism, and Illegal Immigration Control Act of 2005, $109^{\text {th }}$ Congress, 2005, s.202. This Bill was subsequently defeated in the Senate.

110. It is worth noting that according to Lippert, sanctuary providers sometimes resort initially to concealment strategies, and only later to exposure strategies. Lippert, Sanctuary, supra note 7 at 15-16. In such circumstances they are more likely to violate Canadian law.

111.R. v. Greyeyes, supra note 97 at 38 .

112.R. v. Curran, [1978] 1 W.W.R. 255 at 23 (Alta. S.C. (A.D.)) (emphasis added).

113. Bruce Campion-Smith, "Refugees 'freed' from church havens" The Toronto Star (15 December 2004) A2; Eva Salinas, "His church-another version of prison" The Globe and Mail (17 June 2006) S1; "Rallies held to protest man's deportation to India" The Globe and Mail (18 August 2007) S2; Jane Armstrong, "Ottawa grants refugee claimant 60-days” The Globe and Mail (20 August 2007) A5.

Sean Rehaag, B.C.L., LL.B., (McGill), S.J.D. (Toronto), is an assistant professor at the Osgoode Hall Law School at York University. The author would like to thank Ruth Buchanan, Joseph Carens, Susan Coutin, David Dyzenhaus, Randy Lippert, Audrey Macklin, Jennifer Nedelsky, Boaventura de Sousa Santos, and the anonymous peer reviewers at Refuge for their helpful comments on previous drafts. 